\title{
STUDY OF MORPHOLOGIC CHANGE IN POYANG LAKE BASIN CAUSED BY SAND DREDGING USING MULTI-TEMPORAL LANDSAT IMAGES AND DEMS
}

\author{
Shuhua $\mathrm{Qi}^{\mathrm{a}}{ }^{*}$ Xiuxiu Zhang ${ }^{\mathrm{b}} \quad$ Dian Wang $^{\mathrm{b}} \quad$ Jingxuan Zhu $^{\mathrm{b}}$ Chaoyang Fang ${ }^{\mathrm{a}}$ \\ ${ }^{a}$ Ministry of Education Key Laboratory of Poyang Lake Wetland and Watershed Research, Jiangxi Normal of \\ University, Ziyang Road 99\#, Nanchang, China- qishuhua11@163.com \\ ${ }^{\mathrm{b}}$ School of Geography and Environment, Jiangxi Normal University, Ziyang Road 99\#, Nanchang, China- \\ (1991497243, 351857370, 359885091)@qq.com
}

KEY WORDS: Sand dredging, Morphologic change, Landsat image, DEM, Poyang Lake ABSTRACT:

Sand dredging has been practiced in rivers, lakes, harbours and coastal areas in recent years in China mostly because of demand from construction industry as building material. Sand dredging has disturbed aquatic ecosystems by affecting hydrological processes, increasing content of suspended sediments and reducing water clarity. Poyang Lake, connecting with Yangtze River in the lower reaches of the Yangtze River, is the largest fresh water lake in China. Sand dredging in Poyang Lake has been intensified since 2001 because such practice was banned in Yangtze River and profitable. In this study, the morphologic change caused by sand dredging in Poyang Lake basin was analysed by overlaying two DEMs acquired in 1952 and 2010 respectively. Since the reflectance of middle infrared band for sand dredging vessel is much higher than that of water surface, sand dredging vessels were showed as isolated grey points and can be counted in the middle infrared band in 12 Landsat images acquired in flooding season during 2000 2010. Another two Landsat images (with low water level before 2000 and after 2010) were used to evaluate the morphologic change by comparing inundation extent and shoreline shape. The following results was obtained: (1) vessels for sand dredging are mainly distributed in the north of Poyang Lake before 2007, but the dredging area was enlarged to the central region and even to Gan River; (2) sand dredging area reached to about $260.4 \mathrm{~km}^{2}$ and is mainly distributed in the north of Songmen Mountain and has been enlarged to central of Poyang Lake from the distribution of sand vessels since 2007. Sand dredged from Poyang Lake was about $1.99 \times 10^{9} \mathrm{~m}^{3}$ or $2448 \mathrm{Mt}$ assuming sediment bulk density of $1.23 \mathrm{t} \mathrm{m}^{-3}$. It means that the magnitude of sand mining during 2001-2010 is almost ten times of sand depositions in Poyang Lake during 1955-2010; (3) Sand dredging in Poyang Lake has alternated the lake capacity and discharge section area, some of the watercourse in the northern channel was enlarged by more than $1 \mathrm{~km}$ when in low lake level. This study is useful to understand the change of hydrological system, especially the drying up trend in Poyang Lake in recent autumns and winters.

\section{INTRODUCTION}

Poyang Lake, the largest fresh water lake in China, is located at the lower Yangtze River basin of China $\left(28^{\circ} 25^{\prime}-29^{\circ} 45^{\prime} \mathrm{N}, 115^{\circ} 48^{\prime}-116^{\circ} 44^{\prime} \mathrm{E}\right)$. It is fed by the tributaries of the Gan, Fu, Xin, Rao and Xiu rivers and connected to the Yangtze River through the lake mouth in the north (figure 1). Poyang Lake is affected by subtropical monsoon climate with a mean annual precipitation of 1,680 $\mathrm{mm}$ (Ye et al., 2011). Although Poyang Lake basin only occupies an area of $9 \%$ the
Yangtze River Basin, supplies $17 \%$ of annual discharge of Yangtze River. Due to cherish a very abundant biodiversity, Poyang lake wetland was in the first batch of The Ramser Convertion List of Welands of International Importance (The Ramsar Convention 2012). Poyang Lake was also entrusted to store flood water for Yangtze River (Gao et al, 2014) and support a high population densities of about 400-800 persons $/ \mathrm{km}^{2}$ (Shankman et al., 2006).

In the past decades, however, Poyang Lake experienced dramatic morphologic changes due to 


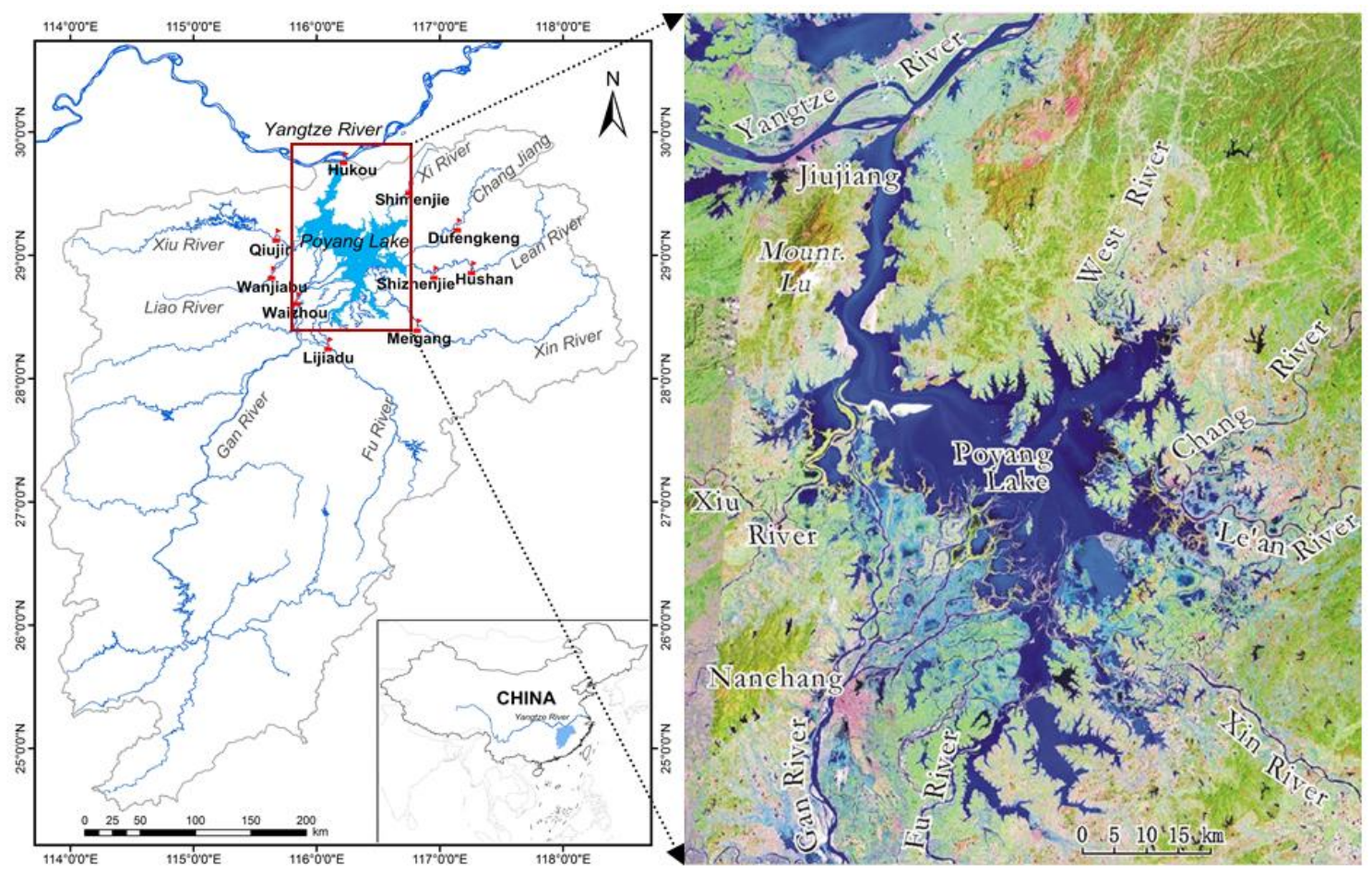

Figure 1: The hydrological system for Poyang Lake watershed and map of Poyang Lake

human activities including sand excavation (Feng et al, 2011) and reclamation for agriculture, fishery, aquaculture and settlements (Qi et al, 2010; Min, 1999). Reclamation and sand excavation caused morphologic changes horizontally and vertically respectively. It is estimated that area of Poyang Lake was reduced from $5160 \mathrm{~km}^{2}$ in 1954 to $3860 \mathrm{~km}^{2}$ in 1998 (Shankman and Liang, 2003). Reclaiming farmland was the most significant activity changing the morphology of Poyang Lake dramatically before 1998.

Demand for sand was increasing during 2001-2010 because of rapid urbanization in the lower Yangtze River valley. And the activity of sand dredging was banned in the Yangtze River in 2000(People's Daily, 2000). Lured by the high profits, sand dredging developed quickly with hundreds of large vessels assembled in Poyang Lake. So the practice of sand dredging in Poyang Lake began in 2001. Sand dredging can cause the increase of water turbid (Wu et al., 2007; Cui et al., 2013; Feng et al., 2012). It was reported that sand dredging in Poyang Lake currently dominates the sediment balance of the lower Yangtze River because of water turbid increase (Gao et al., 2014). Sand excavation also caused an increase of storage capacity. With the assumes that the flow of vessel continued day and night and all vessels have a same carrying capacity of 2000 tonnes, a rate of sand extraction of 236 million $\mathrm{m}^{3}$ year $^{-1}$ in 2005-2006 from Poyang Lake was estimated based on the count of vessels leaving Poyang Lake (de Leeuw et al., 2009). Furthermore, an increase of storage capacity by $0.98 \mathrm{~km}^{3}$ was estimated (Gao et al., 2014)

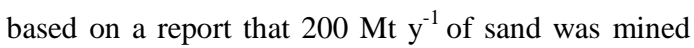

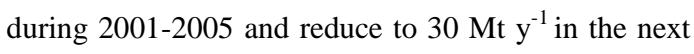
years. These studies can give us some cognition on the magnitude of sand mining in Poyang Lake. These morphologic changes have triggered significant hydrological consequences in the region (Zhong and Chen, 2005). To learn the relationship between these changes of morphology and hydrologic regime more, we need more detail information about sand mining.

This study is to reveal the morphologic changes in Poyang Lake during 2001-2010 caused by sand dredging. The specific objectives are to: (1) calculate the total volume of sand mining and rate of sand excavation every year during 2001-2010; (2) map the main sand mining region; (3) investigate the changes of water surface and morphology of lake bed; (4) 
investigate the hydrologic changes in Poyang Lake caused by sand mining.

\section{DATA AND METHODS}

\subsection{Landsat Images Processing}

One Landsat images (path 121/row 40) with no or little cloud cover were selected for each year during 2000 and 2010 in this study (Table 1). These images were acquired in flood season. And another two images acquired before and after 2001 respectively, with similar low lake level, were used to investigate the morphologic changes caused by the activity of sand excavation. All images were geometrically rectified to WGS84 datum with Universal Transverse Mercatol (UTM) projection and orthorectified using a digital elevation model (DEM) of 1:50,000 using a second-order polynomial and nearest neighbour approach.

\begin{tabular}{|c|c|c|c|c|}
\hline No. & $\begin{array}{c}\text { Image } \\
\text { acquired } \\
\text { date } \\
\text { (YYYY- } \\
\text { MM-DD) }\end{array}$ & $\begin{array}{l}\text { Satellite } \\
\text { /sensor }\end{array}$ & $\begin{array}{c}\text { Water } \\
\text { level } \\
\text { in } \\
\text { Hukou } \\
\text { (m) }\end{array}$ & $\begin{array}{l}\text { Used } \\
\text { in the } \\
\text { study }\end{array}$ \\
\hline 1 & $2000-8-22$ & Landsat7/ETM+ & 13.63 & $\mathrm{a}$ \\
\hline 2 & $2001-6-30$ & Landsat5/TM & 15.02 & $\mathrm{a}$ \\
\hline 3 & $2002-9-29$ & Landsat7/ETM+ & 12.37 & $\mathrm{a}$ \\
\hline 4 & $2003-8-7$ & Landsat7/ETM+ & 14.83 & $\mathrm{a}$ \\
\hline 5 & $2004-6-22$ & Landsat5/TM & 13.55 & $\mathrm{a}$ \\
\hline 6 & $2005-8-12$ & Landsat5/TM & 13.80 & $\mathrm{a}$ \\
\hline 7 & $2006-6-12$ & Landsat5/TM & 14.34 & $\mathrm{a}$ \\
\hline 8 & $2007-8-2$ & Landsat5/TM & 15.98 & a \\
\hline 9 & $2008-5-16$ & Landsat5/TM & 10.73 & $\mathrm{a}$ \\
\hline 10 & $2009-6-4$ & Landsat5/TM & 13.37 & $\mathrm{a}$ \\
\hline 11 & $2010-7-25$ & Landsat5/TM & 17.99 & $\mathrm{a}$ \\
\hline 12 & $2009-2-12$ & Landsat5/TM & 5.68 & $\mathrm{~b}$ \\
\hline 13 & $1993-1-31$ & Landsat5/TM & 6.68 & $\mathrm{~b}$ \\
\hline
\end{tabular}

* a: Counting sand vessels; b: investigating the morphological changes

Table1: Landsat TM/ETM+ images for counting vessels and the concurrent water level in Hukou gauging station

It was revealed that the middle infrared bands 5 and 7 can be used to discriminate vessels from surrounding water ( $\mathrm{Wu}$ et al, 2008). And the fishing boats were too small to affect the reflectance of surrounding water and would not be counted as vessels involving in sand industry. Though it is difficult to make a distinction between sand dredging and sand transporting vessels from remote sensed images, the proportion for the two type of vessel was assumed to be steady in these years. The colour composite map with band 5, 4 and 1 were used to define turbid water region and then the vessels in turbid water were detected by visual interpretation with band 5 .

\subsection{Hydrological Data}

There are eight controlling hydrologic gauging stations at the five tributaries as showed in figure 1. They are named as Waizhou station at Gan River, Lijiadu station at Fu River, Meigang station at Xin River, Hushan, Shizhenjie and Dufengkeng stations at Rao River, as well as Qiujin and Wanjiangfu stations at Xiu River. Daily water discharge and sediment load data for the eight gauging stations and Hukou station gauging the water discharges and sediment load into Yangtze River were obtained from Changiiang Water Resources Commission. These dataset were used to take a view at the change of sediment balance in Poyang Lake. And the water levels from Xingzi gauging station and water discharge from Hukou gauging station were used to investigate the changes of rate of water discharge to Yangtze River from Poyang Lake.

\subsection{Digital Elevation Models and Rate of Sand Dredging}

One digital elevation model (DEM) of the Poyang Lake region was interpolated from 1:25 000 topographic maps with 1-m contour interval produced by Changjiang water resources commission during 1952-1953. Another DEM with a scale of $1: 10,000$ was produced by Jiangxi Provincial administration of Surveying, Mapping and Geoinfomation in 2010. The two Dems were all geometrically rectified to WGS84 datum with Universal Transverse Mercatol (UTM) projection and resampled as 30-m spatial resolution. 
The sand mining region characterized by the distribution of dredging vessels was used as a mask to estimate the dredged sand volume during 2001-2010 by overlaying the two DEMs with the function of cut hill supported by ArcGIS software 10.0. Considering the possible errors in the two DEMs, only these pixels with the elevation difference greater than 1 meter between the two DEMs were considered as sand dredging region. Furthermore, the topographical change was possibly caused by excavating to build levees in the activities of farmland reclamation before 1998. So it is absolutely necessary to combine the distribution of dredging vessels when estimating the storage capacity change caused by sand dredging (volume of dredged sand) during 2001-2010.

\section{RESULT}

\subsection{Morphologic changes in Poyang Lake basin}

This morphologic change in Poyang Lake was caused by deposit of sediment loaded from the mentioned five tributaries in Poyang Lake watershed, building levees in activities of reclaiming land from lakes before 1998 and sand mining after 2001 synthetically. With the operation of subtracting with the two DEMs acquired in 1952 and 2010 (Fig. 2), it showed that (1) sediment deposit was mainly distributed in the delta of Gan River, Songmen Mountain and Eastern of Zhu Lake in the past 60 years. Most of the deposit area was located at the connection of lake and river; (2) the erosion area caused by sand dredging was mainly located in the northern channel connecting lake and Yangtze River (Fig. 3). The practice of sand dredging caused severe man-made erosion and the elevation was lowed more than 10 meters in some of sand mining region. It is possible that the area with slight erosion located in these inner-lakes such as Banghu Lake and Zhuhu Lake were caused by levees building before 1998 or DEM errors.

\subsection{Distribution of Dredging Vessels and magnitude of sand excavation}

Dredging vessels were identified from the infrared band of Landsat images acquired in flooding season

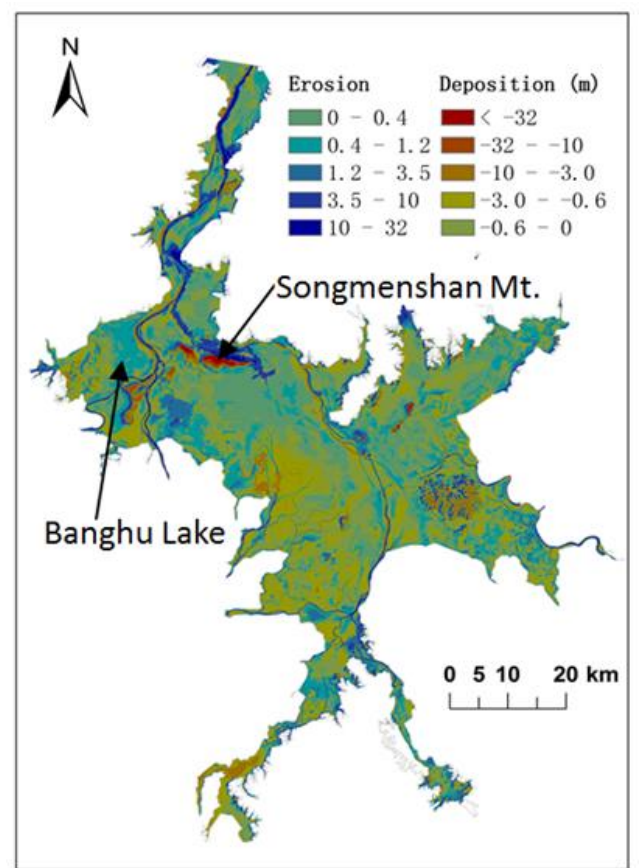

Figure 2: The number of dredging vessles detected

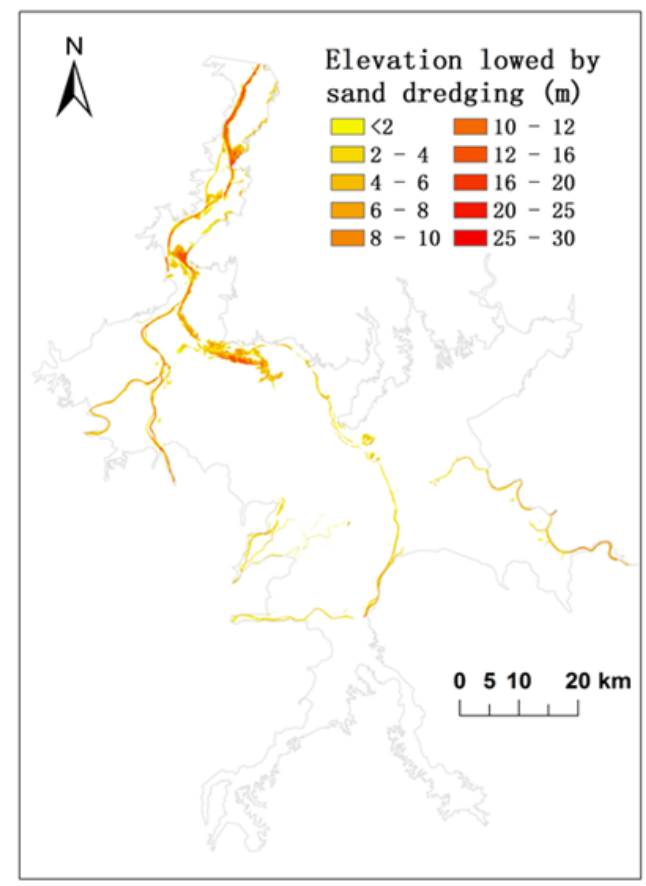

Figure 3: The region with elevation lowed by sand dredging in Poyang Lake during 2001 2010 for every year during 2000-2010 (Fig. 4). Only nine dredging vessels were counted in 2000. But the number of vessels increased dramatically in 2001. And the vessels were mainly assembled at the channel connecting to Yangtze River and the channel connecting north branch of Ganjiang River with 
Poyang Lake before 2006. The activity of dredging sand enlarged southward after 2007. Number of vessels showed an increasing trend before 2007and decreased sharply in 2008 and 2009. Lured by high profits from housing and construction, vessels increased again in 2010 and 2011.

The area of sand dredging was estimated as $260.4 \mathrm{~km}^{2}$ and the volume of sand dredged from Poyang Lake was about $1.99 \times 10^{9} \mathrm{~m}^{3}$ during 2000 2010 with the map of morphologic change and distribution of vessels detected from Landsat images,. Poyang Lake holds about $20 \mathrm{~km}^{3}$ when water level rise to 18 meters above mean sea level relative to the National Vertical Datum of China [NVDC]
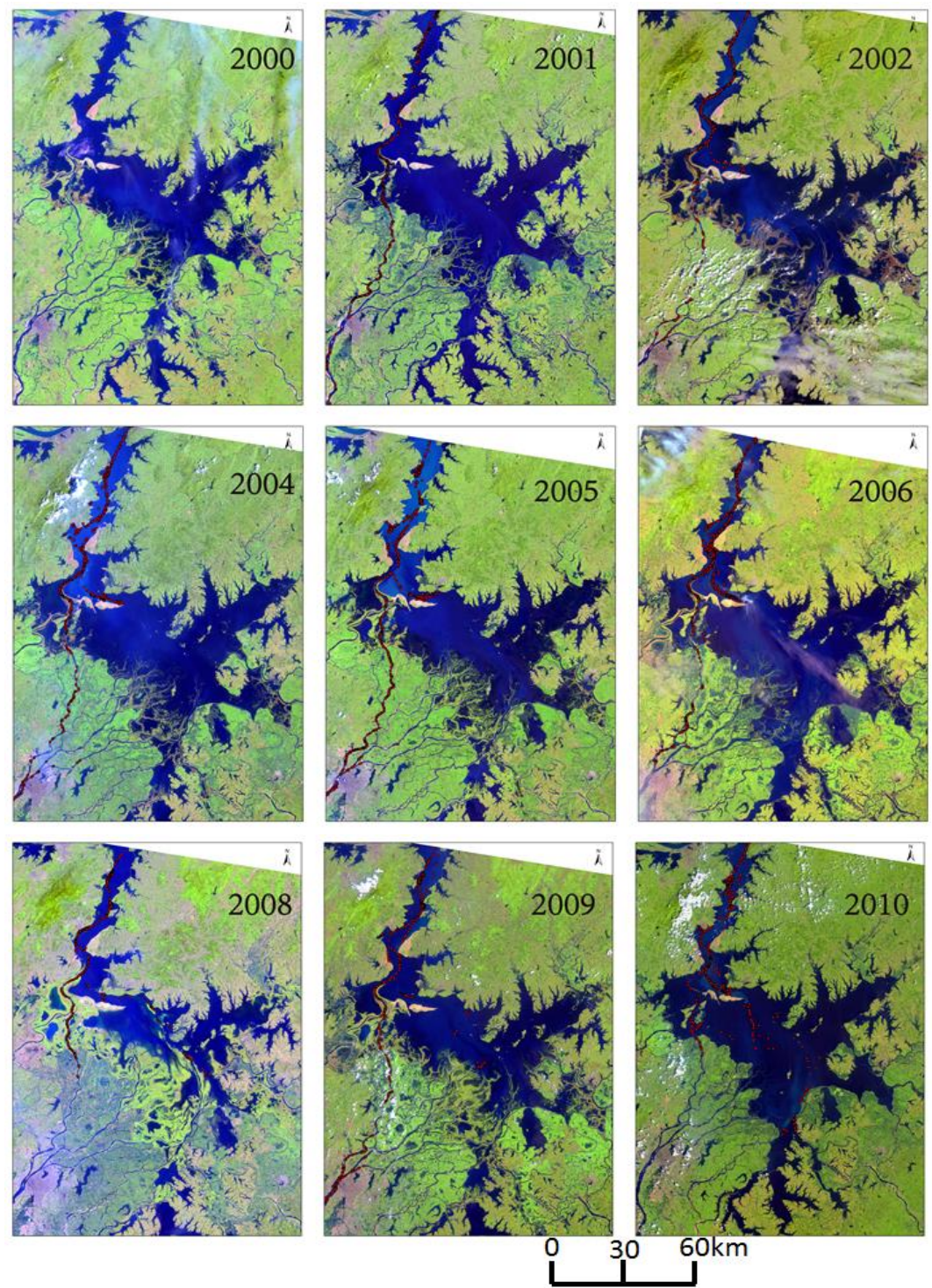

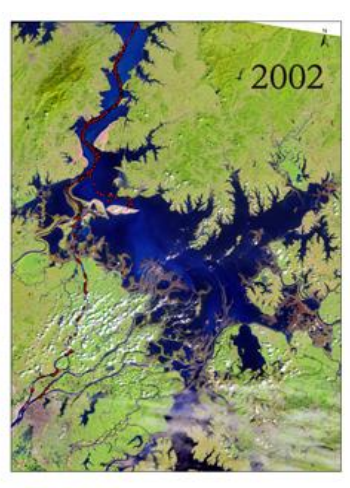

established in 1985 according the relationship between water level and water capacity (Jiangxi Provincial Academy of Sciences et al., 1993). It means that the capacity of Poyang lake was increased about $10 \%$ by sand dredging during 2000 2010. Assuming sediment bulk density of $1.23 \mathrm{t} \mathrm{m}^{-3}$ (Li et al., 2011), about 2448 Mt sand was dredged out for building industry. It was also estimated that the dredged sand was about 230 290Mt yearly during 2005 2007 according the data from Department of maritime affairs, Port and Shipping (Chen, 2009). It means that the magnitude of sand dredged out during 2001 2010 is about 10 times of the sediment budget during 1955 2010.
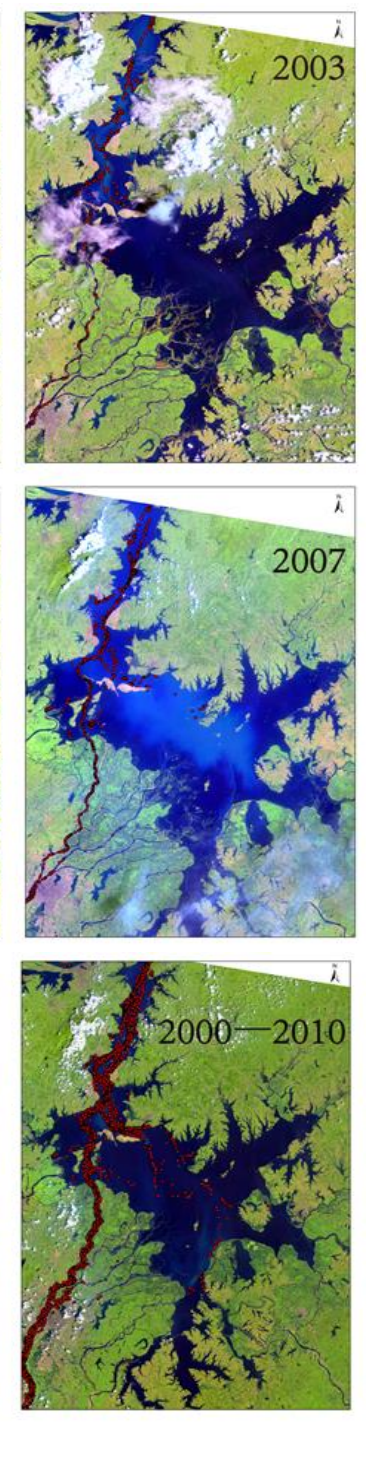

Figure 4: Distribution of dredging vessels detected from Landsat image during 2000-2010

(Note: The red dot was used as legend for vessel) 


\subsection{Hydrological Regime Changes Triggered by Sand Dredging}

The practice of sand dredging had also changed the hydrological regime of Poyang Lake dramatically. Firstly, it changed the water surface extent when in lower water level. From Fig. 7, though the imagery acquired on Jan. $31^{\text {st }} 1993$ (the corresponding water level in Xingzi gauging station was about 6.8m) reflected a higher water level than the imagery acquired on Feb.12 $2^{\text {th }}, 2009$ (water level is about 5.8m), some of the watercourse in the northern channel was enlarged by more than $1 \mathrm{~km}$ when in low lake level (Fig.5). Some watercourse was reshaped chaotically by the discarded coarse sand (Fig.5d).

Secondly, the water flashed into Yangtze was muddied by the practice of sand dredging. From Fig.6, it revealed that water turbidity in Poyang Lake was dramatically increased after 2001. Though the vessels have not decreased, the water turbidity decreased mostly because some of the detected vessels from Landsat images were only berthed in the lake but not in sand dredging practice and also because the sand dredging practice moved southward after 2007. It was argued that the muddied water would do some direct or indirect effects on the survival of rare or endangered species. And the increased sediment output to Yangtze can also do some effects on the river morphology of middle and lower Yangtze River.

Thirdly and not lastly, the enlarged watercourse has caused the water discharge more quickly. It was reported that drought happened in Poyang Lake more frequently in these recent autumns or winters. And the decline in Poyang Lake was attributed to changes of precipitation (Zhang et al., 2011) or weakened blocking effect of the Yangtze River (Liu et al., 2013). But from figure 7 , we noticed that the rate of water discharge from Poyang Lake to Yangtze was greater after 2001 obviously. It could be partly attributed to the enlarged and deepened watercourse that changed streamflow from Poyang Lake to Yangtze. It should be considered as an important factor to interpret the decline of Poyang Lake in recent years.

\section{CONCLUSION}

In this study, several Landsat images were used to detect sand vessels and analysis the practice of sand dredging in Poyang Lake. The morphologic change caused by sand dredging in Poyang Lake was also analysed. It revealed that: (1) vessels for sand dredging are mainly distributed in the north of Poyang Lake before 2008, but the dredging area was enlarged to the central region and even to Gan River; (2) sand dredging area reached to about $260.4 \mathrm{~km}^{2}$ and is mainly distributed in the north of Songmen Mountain and has been enlarged to central of Poyang Lake from the distribution of sand vessels since 2007. Sand dredged from Poyang Lake was about $1.99 \times 10^{9} \mathrm{~m}^{3}$ or 2, $448 \mathrm{Mt}$ assuming sediment bulk density of $1.23 \mathrm{t}$ $\mathrm{m}^{-3}$; (3) Sand dredging in Poyang Lake has alternated the lake capacity, enlarged and deepened the discharge watercourse, and played an important role in the recent decline of Poyang Lake. This study is useful to understand the change of hydrological system, especially the drying up trend in Poyang Lake in recent autumns and winters.

\section{ACKNOWLEDGEMENTS}

This study was supported by the National Natural Science Foundation of China (NSFC, Grant\# 40801169, 41261069); Collaborative Innovation Center for Major Ecological Security Issues of Jiangxi Province and Monitoring Implementation (No. JXS-EW-00); and Opening Fund of the Key Laboratory of Poyang Lake Wetland and Watershed Research (Jiangxi Normal University) (TK2013001). 

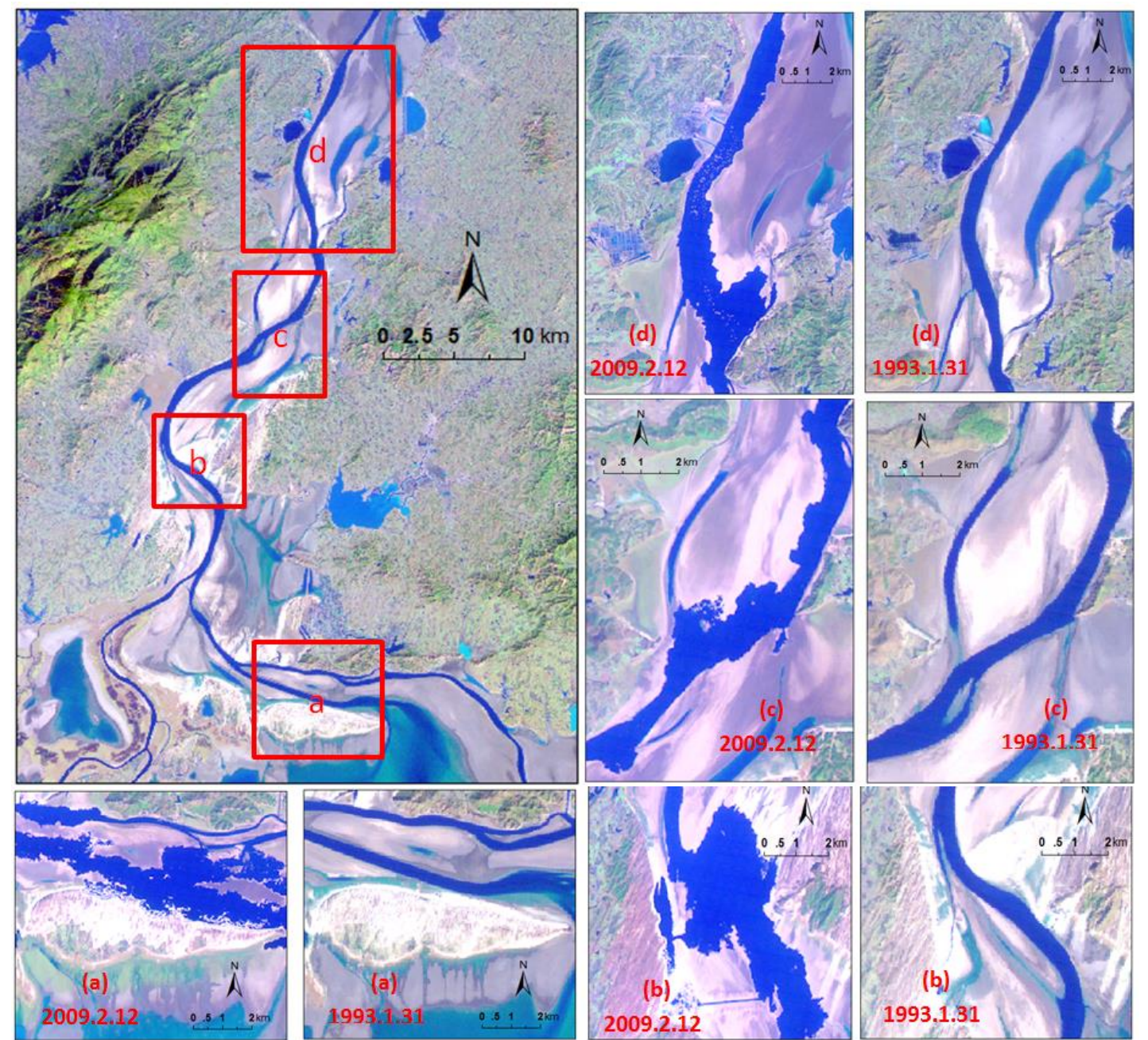

Figure 5: The morphologic changes in Poyang Lake caused by the activity of sand dredging

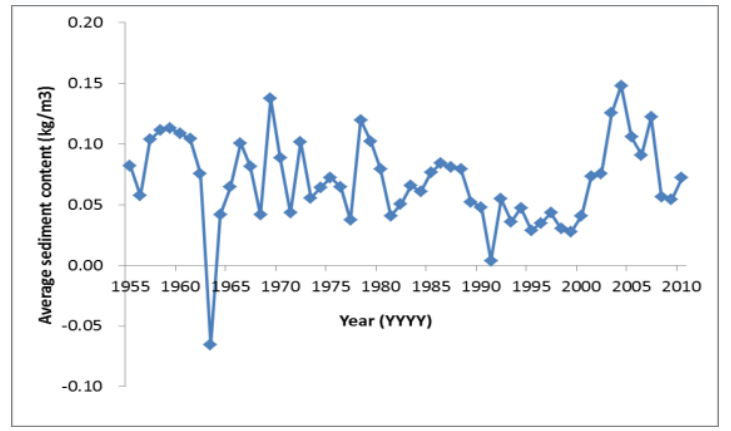

Figure 6: The yearly average loaded sediment content discharged to Yangtze River from Hukou of Poyang

Lake

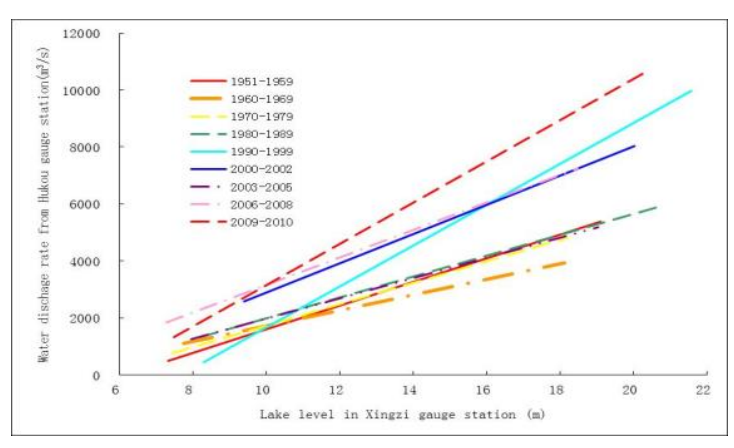

Figure 7: Changes of relationship between lake level and rate of water discharge from Poyang Lake into Yangtze River during 1951-2010

\section{REFERENCES}

Chen Q J. (2010) Effect of unified managing sand-excavating on Poyang Lake in Jiuiang city. Jiangxi Hydrologic Science \& Technology, 36(2):147-148 (In Chinese with English Abstr.)

Cui L J, Wu G F, Liu Y L. (2009) Monitoring the impact of backflow and dredging on water clarity using MODIS images of Poyang Lake, China. Hydrological processes, 23, 342-350

De Leeuw J, Shankman D, Guofeng Wu et al. (2009) 
Strategic assessment of the magnitude and impacts of sand mining in Poyang lake, China. In: Regional environmental change, 10: 95-102

Gao J H, Jia J J, Albert J. K, et al. (2014) Changes in water and sediment exchange between the Changjiang Riverand Poyang Lake under natural and anthropogenic conditions, China. Science of the total environment, 481: 542-553

Feng L, Hu C M, Chen X L, et al. (2011) MODIS observation of the bottom topography and its inter-annual variability of Poyang Lake. Remote sensing of environment, 115: 2729-2741

Feng L, Hu C M, Chen X L, et al. (2012a) Human induced turbidity changes in Poyang Lake between 2000 and 2010: Observations from MODIS. Journal of Geophysical research, Vol. 117, C07006, dio:10.1029/2011JC007864

Feng L, Hu C M, Chen X L, et al (2012b) Assessment of inundation changes of Poyang Lake using MODIS observations between 2000 and 2010. Remote Sensing of Environment, 121:80-92

Jiangxi Provincial Academy of Sciences, Nanjing institute of Geography \& Limnology of CAS, Office of Mountain-River-Lake Development Committee of Jiangxi Province. (1993) Atlas of Poyang Lake. Beijing, Science Press, pp: 5

Li H B, Zhang X F, Xu Q X. (2011) Analysis and prediction of sediment trapped by large-scale reservoir group on upstream of Three Gorges Dam. Eng J Wuhan Univ., 44(4):604 - 12. (In Chinese with English abstr.)

Liu Y B, Wu G P, Zhao X S. (2013)Recent declines in China's largest freshwater lake: trend or regime shift? Environment Res. Lett. (8) 014010(9pp), doi: 10.1088/1748-9326/8/014010

People's Daily (2000) China bans illegal sand mining on Yangtze River. People's Daily 13 December 2000.http://english.peopledaily.com.cn/english/20 0012/13/eng20001213_57716.html. Viewed 6 May 2008

Qi S H, Brown D G, Tian Q, Jiang L G, Zhao T T, Bergen K A (2009) Inundation extent and flood frequency mapping using LANDSAT imagery and digital elevation models. GIScience \& Remote

\section{Sensing 46: 101-127}

Min, Q. (1999) Evaluation of the effects of Poyang Lake reclamation on floods. Yangtze River, 30(7): 30-32 (In Chinese with English Abstr.)

Shankman D, Liang Q, (2003) Landscape Changes and Increasing Flood Frequency in China's Poyang Lake Region. Professional Geographer, 55(4):434-445

Shankman D, Keim B D, and Song J. (2006) Flood frequency in China's Poyang Lake region: Trends and teleconnections. International Journal of Climatology, 26:1255-1266

Ye C, Wu G P, Zhao X S, et al. (2014) Responses of wetland vegetation to droughts and its impact factors in Poyang Lake NationaI Nature Reserve. J. Lake Sci. 26(2): 253-259 ( In Chinese with English abstract)

Wu G F, De Leeuw J, Skidmore A K, et al. (2007) Concurrent monitoring of vessels and water turbidity enhances the strength of evidence in remotely sensed dredging impact assessment. Water Research, 41, pp:3271-3280

Wu G F, De Leeuw J, Skidmore A K, et al. (2008) Performance of Landsat TM in ship detection in turbid waters. International Journal of Applied Earth Observation and Geoinformation, doi: 10.1016/j.jag.2008.07.001

Zhang Q, Liu Y, Yang G, Zhang Z. (2011) Precipitation ang hydrological variations and related associations with large-scale circulation in Poyang Lake basin, China. Hydrological Process.25: 740-751 